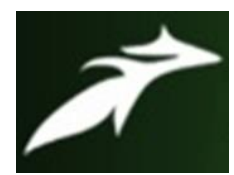

Soma Karmakar et al, International Journal of Advances in Agricultural Science \& Technology,

Vol.9 Issue.1, January-2022, pg. 37-47

ISSN: 2348-1358

Impact Factor: 6.846

NAAS Rating: 3.77

\title{
EFFECT OF INM PRACTICES ON THE MORPHOLOGICAL, PHYSIOLOGICAL AND BIOCHEMICAL PARAMETER OF ARJUN LEAF PRIMARY HOST PLANT OF Antheraea mylitta D.
}

\author{
Soma Karmakar ${ }^{1}$; A.K. Srivastava1; T.Pandiaraj ${ }^{2}$; Jyostna Tirkey ${ }^{2 *}$ \\ ${ }^{1},{ }^{1 *}$ Department of Botany, Ranchi University, Ranchi, India-834008 \\ ${ }^{2}$ Narendra Deva University of Agricultural Technology, Azamgarh, UP, India-276207 \\ 2* Director (Retd) CMER\&TI, Jorhat, Assam-785700 \\ 1 *smarten436@gmail.com
}

DOI: 10.47856/ijaast.2022.v09i01.004

\begin{abstract}
The present study was conducted to investigate the effect of Integrated Nutrient Management practices on the different parameter of Arjun leaf the primary host plant of Antheraea mylitta D. Eleven different combination with three replication were laid out in Randomized Complete Block Design at the field of Research Extension Centre, Kapistha. The obtained results showed that morphological, Physiological and Biochemical parameter of Arjun leaf showed significant difference. The Arjun leaf length was recorded highest in $\mathrm{K}_{11}(17 \mathrm{~cm})$ was on par with $\mathrm{K}_{9}(17 \mathrm{~cm})$. Highest leaf breadth was recorded in $\mathrm{K}_{10}(6.2 \mathrm{~cm})$ was applied with $75 \% \mathrm{RDF}+$ Poultry manure+ $\mathrm{AB}+\mathrm{PSB}$. Leaf weight was recorded highest in $\mathrm{K}_{7}(2.84 \mathrm{~g})$, lowest in $\mathrm{K}_{1}(1.21 \mathrm{~g})$. Number of leaves was recorded highest in $K_{6}$ (1816) over the control. The leaf yield was recorded highest in $K_{11}$ (3735). Leaves dry matter production was highest in $\mathrm{K}_{8}(469.56 \mathrm{~g})$ over the control. Relative water content was highest in $\mathrm{K}_{5}(87.3 \%)$. The initial Electrical Conductivity was recorded highest in $\mathrm{K}_{9}\left(0.037 \mathrm{dSm}^{-1}\right)$ and after $10 \mathrm{~min} \mathrm{EC}$ was found to highest in $\mathrm{K}_{9}\left(0.111 \mathrm{dSm}^{-1}\right)$. The Chlorophyll 'a' was recorded highest in $\mathrm{K}_{9}$ (3.39), Chl'b'(2.36)and total chlorophyll in $\mathrm{K}_{9}(5.75)$ was recorded highest. The result were found significant due to effect of INM practices which provided the nutrients element needed by plants.
\end{abstract}

Keywords: Antheraea mylitta; Chlorophyll; Nutrient; Poultry manure and Relative water content 


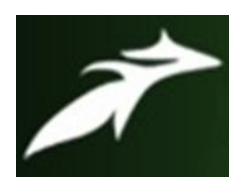

Soma Karmakar et al, International Journal of Advances in Agricultural Science \& Technology, Vol.9 Issue.1, January-2022, pg. 37-47

ISSN: 2348-1358

Impact Factor: 6.846

NAAS Rating: 3.77

\section{INTRODUCTION}

Forest or wild sericulture is known as non-mulberry sericulture. It arrest forest destruction by permitting the utilization of natural wealth (Jolly et al, 2019; Fening et al., 2008). Tasar culture can be carried out in remote forest villages as it does not require electricity, complex machinery, specialized skills etc. it helps in preservation of tradition, skills and improves the status of life in the rural areas by providing attractive source of income (Rubia bukhari et al., 2019). Indiscriminate use of chemical fertilizers leads to environmental pollution as well as deteriorate soil health. Which lead to thrust on organic farming for an eco-friendly sericulture and its potential for improving the sericulture industry. Which improve the leaf, cocoon as well as silk production and quality (Chowdhury P et al., 2009). Sericulture depends on many factors which ensure productivity and profitability such as climatic condition, soil health, environmental factors and nutrient management etc. Out of these factors soil health and nutrient management are the most important factor as the yield and quality of leaves directly or indirectly depend on" how the soil is handled" soil is the key factor in this regard (Karlen D.L et al., 1997). Forest aboriginal had started rearing of tasar silkworms for centuries. Tasar is a variety of silk mainly produced by tropical tasar silkworm (Antheraea mylitta D) and temperate tasar silkworm (Antheraea proyeli $\mathrm{J}$ ) by feeding on primary host plants (Arjun, Asan and Sal), Dozens of secondary host plants and Oak plants (Querecus sp.)(Vishaka et al., 2020).

The life cycle of Tasar silkworm consist of four stages-Egg, Larva, Pupa and Adult. Egg-The egg is oval in shape, dorso-ventrally flattened and bilaterally symmetrical along the anterio-posterior axis. Larva- The newly hatched larva is dull brownish yellow with black head, measuring about $7 \mathrm{~mm}$ long and $1 \mathrm{~mm}$ diameter and weighs about $8 \mathrm{mg}$. At maturity measures about $13 \mathrm{~cm}$ long and $2.1 \mathrm{~cm}$ diameter and weighs about $50 \mathrm{gm}$. The fully grown larva spins the cocoon by taking the support of one or two leaves and a peduncle to firmly cling to the plant and this is the stage which is exploited for the production of silk. The pupa is killed by boiling in hot water and the thread from the cocoon is extracted. Pupa- It is the resting stage which last for days to months. Moths-Females are bigger $(4.5 \mathrm{~cm})$ with a broad abdomen and narrow bipectinate antennae of $1.5 \mathrm{~cm}$ long. Males are smaller $(4.0 \mathrm{~cm})$ with a narrow abdomen and broad antennae. Female lays around 200-300 eggs (Rubia bukhari et al.,2019).

The growth and development of tasar silkworm larvae depend on nutritional contents of leaves (Srivastava et al.,2017). The chemical composition of leaves greatly varies based on genotype and application of manures fertilizers. The chlorophyll coloration is related to the amount of nutrients absorbed by the plant from the soil (Follet et al.,1981). In vermicompost nutrient are present in plant available form such as nitrates, phosphates and exchangeable calcium and soluble potassium (Edwards,1998, Orozco,1996) and improves the soil physical properties by decreasing bulk density and by increasing the soil water holding capacity. Organic composts are source of plant nutrients which are valuable and inexpensive fertilizer (Khashayar rigi,2014) that create less 


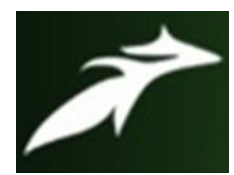

Soma Karmakar et al, International Journal of Advances in Agricultural Science \& Technology, Vol.9 Issue.1, January-2022, pg. 37-47

ISSN: 2348-1358

Impact Factor: 6.846

NAAS Rating: 3.77

environmental pollution than chemical composts, due to their biological effect and modification of physical and chemical characteristics of soil because the nutrients present are released slowly to be used by the plant (Roe,1997).Organic agriculture promotes and enhances agro-ecosystem, health including biodiversity, biological cycles and soil biological activity (Samman et al.,2008).Microorganism present in the soil fixes atmospheric nitrogen, solubilise the insoluble phosphate to soluble phosphate, synthesize growth promoting substances and helps in decomposition of plant residues by releasing vital nutrients and increasing the soil humic contents (Wu et al.,2005). Bio-fertilization is a very safe process for human, animal and environment which lower the pollution and cost of fertilization is reduced and also improves the soil biota and minimize the use of chemical fertilizer (Sabashini et al.,2007). The protein content of leaves is directly correlated to the weight of cocoons for normal silk production during the $5^{\text {th }}$ instars of the caterpillar water content of leaves serve as one criteria for assessing the quality (Kafian Alexander,1960, Parpieu,B.A.1968). The objective of the present study was to assess the effect of INM practices on the morphological, physiological and biochemical parameters of Arjun leaf.

\section{MATERIALS AND METHODS}

The present investigation was carried out at Research Extension Centre, Kapistha to assess the effect of Integrated Nutrient Management practices on the morphological, physiological and biochemical parameters of Arjun leaf. Eleven different combinations with three replication were laid out in Randomized Complete Block Design (Table1).

Table 1: Treatment details (REC, Kapistha)

\begin{tabular}{|cl|l|}
\hline $\begin{array}{c}\text { Treatments } \\
\text { denotes }\end{array}$ & \\
\hline $\mathrm{K}_{1}$ & $:$ & Absolute control \\
\hline $\mathrm{K}_{2}$ & $:$ & RDF(N,P and $\mathrm{K} @ 100-50-50 \mathrm{~kg} / \mathrm{h} /$ year $)$ \\
\hline $\mathrm{K}_{3}$ & $:$ & AB \\
\hline $\mathrm{K}_{4}$ & $:$ & PSB \\
\hline $\mathrm{K}_{5}$ & $:$ & $75 \%$ RDF+PSB \\
\hline $\mathrm{K}_{6}$ & $:$ & $75 \% \mathrm{RDF}+\mathrm{AB}$ \\
\hline $\mathrm{K}_{7}$ & $:$ AB+PSB \\
\hline $\mathrm{K}_{8}$ & $:$ Poultry manure \\
\hline
\end{tabular}




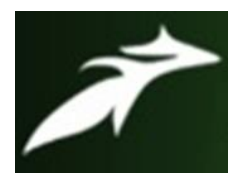

Soma Karmakar et al, International Journal of Advances in Agricultural Science \& Technology, Vol.9 Issue.1, January-2022, pg. 37-47

ISSN: 2348-1358

Impact Factor: 6.846

NAAS Rating: 3.77

\begin{tabular}{|lll|}
\hline $\mathrm{K}_{9}$ & $:$ & Sheep manure \\
\hline $\mathrm{K}_{10}$ & $:$ & $75 \% \mathrm{RDF}+$ Poultry manure $+\mathrm{AB}+\mathrm{PSB}$ \\
\hline $\mathrm{K}_{11}$ & $:$ & $75 \%$ RDF+ Sheep manure $+\mathrm{AB}+\mathrm{PSB}$ \\
\hline
\end{tabular}

\section{Sample collection and Processing}

Leaf sample were collected from each treatments for further analysis.

\section{Morphological parameters}

The following growth parameters were recorded after the treatments (Mallapa,2015).

\subsection{Length and Breadth of Leaf $(\mathrm{cm})$}

Length and Breadth of leaf were measured from each treatment.

\subsection{Weight of Single Leaf (g)}

Weight of single leaf from each treatment were recorded

\subsection{Number of leaves plant ${ }^{-1}$}

Total number of leaves per treatment were counted.

\subsection{Leaf Yield (g plant ${ }^{-1}$ )}

Leaf yield per plant was recorded on fresh weight basis in grams.

\subsection{Dry matter production of leaf $\left(\mathrm{g} \mathrm{plant}^{-1}\right)$}

Leaves of each treatment were collected randomly and were air dried followed by oven drying $60^{\circ} \mathrm{C}$ to a constant weight and expressed in grams.

\section{Physiological Parameters}

\subsection{Relative water content (RWC)}

The RWC of the leaf tissue was estimated according to the method (Slatyer, R.D.,1955). About one $\mathrm{g}$ fresh leaves sample was weighed and dipped in $20 \mathrm{ml}$ distilled water for three hour. After three hours, the turgid weight of the leaves was taken and then kept for drying in $90^{\circ} \mathrm{C}$ in a hot air oven till the weight became constant. It was expressed in percentage. The RWC was computed as

RWC \%

Fresh weight of leaf -Dry weight of leaf

$$
\text { Turgid weight-Dry weight }
$$




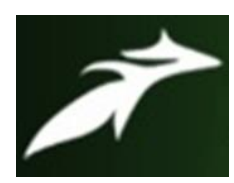

Soma Karmakar et al, International Journal of Advances in Agricultural Science \& Technology, Vol.9 Issue.1, January-2022, pg. 37-47

ISSN: 2348-1358

Impact Factor: 6.846

NAAS Rating: 3.77

\subsection{Electrical Conductivity of leaf}

The electrical conductivity of the leaf was estimated using the method of Bower and Wilcox, 1965. About $1 \mathrm{gm}$ of fresh leaf was taken then dipped in $50 \mathrm{ml}$ distilled water for $10 \mathrm{~min}$. After $10 \mathrm{~min}$ EC was measured using an electrical conductivity meter and then kept in a water bath at $60^{\circ} \mathrm{C}$ for 10 min and EC was measured.

\section{Biochemical parameters}

\subsection{Chlorophyll estimation}

Chlorophyll content of the leaves was determined by procedure described by Hiscox and Israelstam,1979 . The Chlorophyll a, b and total content of leaf (mg/g fresh weight) were computed using the formula suggested by Arnon, 1949 .

\begin{tabular}{|c|c|c|c|c|}
\hline \multirow{2}{*}{ Chlorophyll 'a' } & \multirow{2}{*}{$=$} & 12.7(A663)- 2.69( A645) & \multirow{2}{*}{$x$} & \multirow{2}{*}{ Volumes } \\
\hline & & $1000 \mathrm{~g} \times$ Weight of leaves $(\mathrm{g})$ & & \\
\hline \multirow{2}{*}{ Chlorophyll 'b' } & & 22.9(A645)-4.68(A663) & \multirow{2}{*}{$x$} & \multirow{2}{*}{ Volumes } \\
\hline & $=$ & $1000 \mathrm{~g} \times$ Weight of leaves $(\mathrm{g})$ & & \\
\hline \multirow{2}{*}{ tal Chlorophyll } & & $22.2(\mathrm{~A} 645)-8.02(663)$ & \multirow{2}{*}{$x$} & \multirow{2}{*}{ Volumes } \\
\hline & & $1000 \mathrm{~g} \times$ Weight of leaves $(\mathrm{g})$ & & \\
\hline
\end{tabular}

\section{Statistical Analysis}

Statistical analysis was carried out using ANOVA and SPSS 20.0 and Duncan's Multiple Range Test (DMRT) was used to determine significance of the difference between individuals means (Gomez and Gomez,1984).

\section{RESULTS AND DISCUSSION}

The leaf morphological, physiological and biochemical parameters were found to be significant.

\section{Morphological parameters of Arjun leaf}

\section{a. Growth parameters}

The organic resources improves growth parameters, leaf yield and quality due to proper decomposition, mineralization, solubilizing effects and sufficient nutrient availability. This was corroborated with the finding of Das et al.,1990, Setua et al.,2007 and Sudhakar et al.,2000 and due to slow and steady release of nutrients in addition to supply of important macro and micronutrients besides supply of $\mathrm{N}$ and $\mathrm{P}$ by nitrogen fixing bacteria and phosphorus solubilizing bio-inoculants respectively(Khan and Pariari,2012, Rashmi et al,2006 and B. Mallapa et al,2016). The leaf length and breadth showed significant difference after the application of different treatments. Highest mean of leaf length $17 \mathrm{~cm}$ 


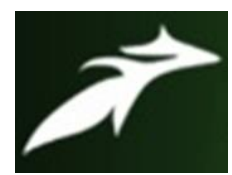

Soma Karmakar et al, International Journal of Advances in Agricultural Science \& Technology, Vol.9 Issue.1, January-2022, pg. 37-47

ISSN: 2348-1358

Impact Factor: 6.846

NAAS Rating: 3.77

was recorded in $\mathrm{K}_{9}$ and $\mathrm{K}_{11}$ while mean of leaf breadth was recorded in $\mathrm{K}_{10}(6.2 \mathrm{~cm})$ was on par with $\mathrm{K}_{7}$ $(6 \mathrm{~cm})$. The leaf weight was recorded highest in $\mathrm{K}_{7}(2.84 \mathrm{gm})$ was applied with $\mathrm{AB}+\mathrm{PSB}$. Highest number of leaves was recorded in $\mathrm{K}_{6}(1816)$ which was applied with $75 \% \mathrm{RDF}+\mathrm{AB}$ followed by $\mathrm{K}_{8}(1806)$. Increase in number of leaves per plant, average leaf length, leaf width, plant girth was reported by P.S. Choudhuri et al.,2016, M.K.Singh,2012 and B. Mallapa et al.,2016 reported increase in leaf number per plant. Increase in plant height, number of shoots, number of leaves, leaf area index, dry matter production and leaf yield in mulberry was reported by Dalal and Nandkar,2006 and Rajeshwari et al.,2006. The fresh leaf yield ranged from 1542-3735g/plant with a mean of 3094.78 $\mathrm{g} / \mathrm{plant}$. The highest leaf yield was recorded in $\mathrm{K}_{11}(3735 \mathrm{~g})$ was applied with $75 \% \mathrm{RDF}+$ Sheep manure $+\mathrm{AB}+\mathrm{PSB}$ was followed by $\mathrm{K}_{9}(3730 \mathrm{~g})$ and $\mathrm{K}_{8}(3718 \mathrm{~g})$. Increase in fresh weight of leaves, dry weight of leaves of tomato due to combined application of organic and inorganic fertilizer was reported by Meenakumari $\mathrm{T}$ and Shekhar M,2012. Leaf weight is directly related to the level of $\mathrm{N}$ applied (Pushkarnath 1976 and Taya et al.,1994). The leaf dry matter production ranged from 114.75-469.56 $\mathrm{g} /$ plant with a mean of $267.88 \mathrm{~g} / \mathrm{plant}$. The highest dry matter was recorded in $\mathrm{K}_{8}(469.56 \mathrm{~g})$ was applied with poultry manure. Lowest dry matter was recorded in control i.e. $\mathrm{K}_{1}(114.75 \mathrm{~g})$. Increase in dry matter production is due to release of nitrogen from the organic waste and fixation of nitrogen by the biofertilizer which contributed to the higher nitrogen uptake (V. Kumar et al.,2007).Increase in dry matter content was reported by R.L. Ram et al.,2017.

Table 2. Leaf morphological characters [leaf length $(\mathrm{cm})$, breadth $(\mathrm{cm})$, leaf weight $\left(\mathrm{g} \mathrm{leaf}^{-1}\right)$, No. of leaves plant $^{-1}$, leaf yield plant ${ }^{-1}$ and total leaves dry matter production $\left.\left(\mathrm{g} \mathrm{plant}^{-1}\right)\right]$ Terminalia arjuna as influenced by various INM practices at REC, Kapistha

\begin{tabular}{|c|c|c|c|c|c|c|}
\hline Treatments & Leaf length & $\begin{array}{c}\text { Leaf } \\
\text { breadth }\end{array}$ & $\begin{array}{c}\text { Leaf } \\
\text { weight }\end{array}$ & $\begin{array}{c}\text { No. of } \\
\text { leaves }\end{array}$ & Leaf yield & $\begin{array}{c}\text { Leaves } \\
\text { DMP }\end{array}$ \\
\hline K1 & $11.6^{\mathrm{g}}$ & $4.2^{\mathrm{g}}$ & $1.21^{\mathrm{d}}$ & $1275^{\mathrm{e}}$ & $1542^{\mathrm{f}}$ & $114.75^{\mathrm{i}}$ \\
\hline $\mathrm{K} 2$ & $12.5^{\mathrm{f}}$ & $4.6^{\mathrm{f}}$ & $1.35^{\mathrm{d}}$ & $1345^{\mathrm{e}}$ & $1814^{\mathrm{e}}$ & $161.4^{\mathrm{h}}$ \\
\hline $\mathrm{K} 3$ & $13.2^{\mathrm{ef}}$ & $4.9^{\mathrm{e}}$ & $1.82^{\mathrm{c}}$ & $1619^{\mathrm{c}}$ & $2941^{\mathrm{d}}$ & $242.85^{\mathrm{e}}$ \\
\hline $\mathrm{K} 4$ & $14.0^{\mathrm{cd}}$ & $5.9^{\mathrm{b}}$ & $1.84^{\mathrm{c}}$ & $1766^{\mathrm{ab}}$ & $3242^{\mathrm{c}}$ & $211.92^{\mathrm{f}}$ \\
\hline $\mathrm{K} 5$ & $14.4^{\mathrm{bc}}$ & $5.2^{\mathrm{d}}$ & $1.74^{\mathrm{c}}$ & $1698^{\mathrm{b}}$ & $2961^{\mathrm{d}}$ & $365.58^{\mathrm{b}}$ \\
\hline $\mathrm{K} 6$ & $14.9^{\mathrm{b}}$ & $5.8^{\mathrm{bc}}$ & $1.96^{\mathrm{c}}$ & $1816^{\mathrm{a}}$ & $3557^{\mathrm{b}}$ & $308.72^{\mathrm{c}}$ \\
\hline $\mathrm{K} 7$ & $16.3^{\mathrm{a}}$ & $6^{\mathrm{ab}}$ & $2.84^{\mathrm{a}}$ & $1309^{\mathrm{e}}$ & $3665^{\mathrm{ab}}$ & $261.8^{\mathrm{d}}$ \\
\hline $\mathrm{K} 8$ & $15^{\mathrm{b}}$ & $5^{\mathrm{de}}$ & $2.08^{\mathrm{c}}$ & $1806^{\mathrm{a}}$ & $3718^{\mathrm{ab}}$ & $469.56^{\mathrm{a}}$ \\
\hline
\end{tabular}




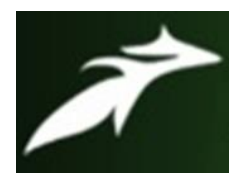

Soma Karmakar et al, International Journal of Advances in Agricultural Science \& Technology, Vol.9 Issue.1, January-2022, pg. 37-47

ISSN: 2348-1358

Impact Factor: 6.846

NAAS Rating: 3.77

\begin{tabular}{|c|c|c|c|c|c|c|}
\hline K9 & $17^{\mathrm{a}}$ & $5.6^{\mathrm{c}}$ & $2.56^{\mathrm{c}}$ & $1452^{\mathrm{d}}$ & $3720^{\mathrm{ab}}$ & $188.76^{\mathrm{g}}$ \\
\hline K10 & $13.6^{\mathrm{de}}$ & $6.2^{\mathrm{a}}$ & $2.16^{\mathrm{b}}$ & $1457^{\mathrm{d}}$ & $3142^{\mathrm{c}}$ & $305.97^{\mathrm{c}}$ \\
\hline K11 & $17^{\mathrm{a}}$ & $5.8^{\mathrm{bc}}$ & $2.44^{\mathrm{c}}$ & $1509^{d}$ & $3735^{\mathrm{a}}$ & $315.38^{\mathrm{c}}$ \\
\hline Mean & 14.50 & 5.38 & 2.00 & 1550 & 3094.78 & 267.88 \\
\hline Range & $11.60-17.00$ & $4.20-6.20$ & $1.21-2.84$ & $1275-1816$ & $1542-3735$ & $\begin{array}{r}114.75- \\
469.56\end{array}$ \\
\hline 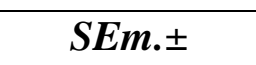 & 0.27 & 0.08 & 0.03 & 24.66 & 48.18 & 5.02 \\
\hline$L S D(P=0.05)$ & 0.79 & 0.23 & 0.08 & 73.27 & 143.12 & 14.90 \\
\hline
\end{tabular}

2. Physiological parameters of Arjun leaf

\section{a. Relative water and EC content}

The physiological parameters were found to be significantly due to INM practices. The Relative Water Content (RWC) ranged from $66.83-87.30(\%)$ with a mean of $77.96 \%$. The highest RWC was observed in treatment $\mathrm{K}_{5}(87.35 \%)$ was applied with $75 \% \mathrm{RDF}+\mathrm{PSB}$ was followed by $\mathrm{K}_{7}(85.76 \%)$. RWC indicate the internal plant water status under drought conditions(Parsons and Howe,1984).Leaf pigment get damaged by water deficit as reported by (Montag U and Woo,1990; Nilsen and Orcuts,1996), due to production of Reactive Oxygen Species(ROS) such as $\mathrm{O}_{2}{ }^{-}$and $\mathrm{H}_{2} \mathrm{O}_{2}$ lead to lipid peroxidation and thus chlorophyll destruction(Mirnoff,1993, Foyer et al.,1994). The Chlorophyll is destroyed by water deficit and formation also prevented (Lessani and Mojtahedi, 2002).The EC content was found significant due to different nutrient application. The EC content ranged from $0.025-0.037 \mathrm{dSm}^{-1}$ with a mean of $0.031 \mathrm{dSm}^{-1}$ and after $10 \mathrm{~min}$ water bath treatment the EC ranged from $0.057-0.111 \mathrm{dSm}^{-1}$ with a mean of $0.090 \mathrm{dSm}^{-1}$. The EC index salt concentration and related to the amount of ions available to plants in the root zone (Nemali KS, Van lersel MW,2004).

Table 3 Leaf quality characters [ Relative water content $(\%)$ and electrical conductivity of leaves (dS m* $\left.{ }^{1}\right)$ ] of Terminalia arjuna as influenced by various INM practices at REC, Kapistha

\begin{tabular}{|c|c|c|c|}
\hline \multirow{2}{*}{ Treatments } & \multirow{2}{*}{ RWC } & \multicolumn{2}{|c|}{ EC content } \\
\cline { 3 - 4 } & & Initial & $\begin{array}{c}\text { After 10 } \\
\text { minutes }\end{array}$ \\
\hline $\mathrm{K} 1$ & $66.83^{1}$ & 0.025 & 0.057 \\
\hline $\mathrm{K} 2$ & $68.17^{\mathrm{h}}$ & 0.026 & 0.072 \\
\hline
\end{tabular}




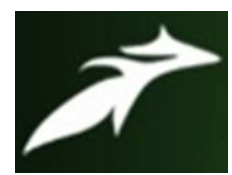

Soma Karmakar et al, International Journal of Advances in Agricultural Science \& Technology, Vol.9 Issue.1, January-2022, pg. 37-47

ISSN: 2348-1358

Impact Factor: 6.846

NAAS Rating: 3.77

\begin{tabular}{|c|c|c|c|}
\hline K3 & $84.12^{c}$ & 0.027 & 0.076 \\
\hline $\mathrm{K} 4$ & $83.22^{\mathrm{d}}$ & 0.037 & 0.102 \\
\hline K5 & $87.3^{\mathrm{a}}$ & 0.027 & 0.079 \\
\hline K6 & $74.89^{\mathrm{fg}}$ & 0.030 & 0.090 \\
\hline K7 & $85.76^{\mathrm{b}}$ & 0.032 & 0.105 \\
\hline K8 & $77.74^{\mathrm{e}}$ & 0.030 & 0.095 \\
\hline K9 & $82.56^{\mathrm{e}}$ & 0.037 & 0.111 \\
\hline K10 & $77.69^{f}$ & 0.032 & 0.098 \\
\hline K11 & $69.36^{\mathrm{g}}$ & 0.034 & 0.103 \\
\hline Mean & 77.96 & 0.031 & 0.090 \\
\hline Range & $66.83-87.30$ & $0.025-0.037$ & $0.057-0.111$ \\
\hline SEm.土 & 0.82 & 0.001 & 0.001 \\
\hline$L S D(P=0.05)$ & 2.43 & 0.002 & 0.003 \\
\hline
\end{tabular}

\section{Biochemical parameters of Arjun leaf}

\section{a. Chlorophyll content}

The chlorophyll content was recorded significant. The chlorophyll'a' ranged from 1.10-3.39(mg/l) with a mean of $2.073 \mathrm{mg} / \mathrm{l}$. The highest chl 'a' was recorded in $\mathrm{K}_{9}(3.39 \mathrm{mg} / \mathrm{l})$ was applied with sheep manure. The chl ' $b$ ' was recorded highest in $\mathrm{K}_{9}(2.36 \mathrm{mg} / \mathrm{l})$ and lowest in $\mathrm{K}_{1}(0.58 \mathrm{mg} / \mathrm{l})$. The total chlorophyll ranged from $1.68-5.75(\mathrm{mg} / \mathrm{l})$ with a mean of $3.407 \mathrm{mg} / \mathrm{l}$ with highest mean in $\mathrm{K}_{9}$ $(5.75 \mathrm{mg} / \mathrm{l})$ and ;lowest mean in $\mathrm{K}_{1}(1.68 \mathrm{mg} / \mathrm{l})$. chlorophyll content Increase due to fertilization. Fertilization enhances the formation of pigments and thus increases chlorophyll (Amany S Al-Eray et al.,2016).Nitrogen is one of the structural element of chlorophyll and protein molecules. Fertilization with $\mathrm{N}$ influence the chlorophyll content by affecting the formation of chloroplasts and accumulation of chlorophyll (Ray Tucher,2004). Nitrogen plays a greater role in improving the chlorophyll synthesis because it is essential constituents of photosynthesis (Singhal et al.,2000). Rashmi et al.,(2009) observed that the total chlorophyll content was maximum with the application of chemical fertilizers along with biofertilizers, compost, vermicompost, green manure and castor cake. 


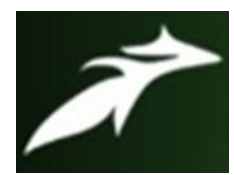

Soma Karmakar et al, International Journal of Advances in Agricultural Science \& Technology, Vol.9 Issue.1, January-2022, pg. 37-47

ISSN: 2348-1358

Impact Factor: 6.846

NAAS Rating: 3.77

Table 4 Biochemical characters [crude protein (\%), total carbohydrate $\left(\mathrm{mg} \mathrm{g}^{-1}\right)$ ] and Chlorophyll(mg/l) conent of Terminalia arjuna leaves as influenced by various INM practices at REC, Kapistha

\begin{tabular}{|c|c|c|c|}
\hline \multirow{2}{*}{ Treatments } & \multicolumn{3}{|c|}{ Chlorophyll content } \\
\cline { 2 - 4 } & $\begin{array}{c}\text { Chlorophyll } \\
\text { 'a' }\end{array}$ & Chlorophyll 'b' & $\begin{array}{c}\text { Total } \\
\text { Chlorophyll }\end{array}$ \\
\hline K1 & 1.1 & 0.58 & 1.68 \\
\hline K2 & 1.43 & 0.83 & 2.26 \\
\hline K3 & 1.55 & 0.76 & 2.31 \\
\hline K4 & 1.74 & 1.02 & 2.76 \\
\hline K5 & 1.90 & 1.18 & 3.08 \\
\hline K6 & 2.42 & 1.23 & 3.65 \\
\hline K7 & 2.82 & 1.52 & 4.34 \\
\hline K8 & 2.40 & 1.37 & 3.77 \\
\hline K9 & 3.39 & 2.36 & 5.75 \\
\hline K10 & 2.15 & 2.06 & 4.21 \\
\hline K11 & 1.90 & 1.77 & 3.67 \\
\hline Mean & $\mathbf{2 . 0 7 3}$ & $\mathbf{1 . 3 3 5}$ & $\mathbf{3 . 4 0 7}$ \\
\hline Range & $\mathbf{1 . 1 0 - 3 . 3 9}$ & $\mathbf{0 . 5 8 - 2 . 3 6}$ & $\mathbf{1 . 6 8 - 5 . 7 5}$ \\
\hline SEm. & $\mathbf{0 . 0 4}$ & $\mathbf{0 . 0 2}$ & $\mathbf{0 . 0 5}$ \\
\hline LSD (P=0.05) & $\mathbf{0 . 1 2}$ & $\mathbf{0 . 0 7}$ & $\mathbf{0 . 1 5}$ \\
\hline
\end{tabular}

\section{CONCLUSION}

Find indicate that application of INM practices had improved the morphological, physiological and biochemical parameters of Arjun leaf. Based on the present results, it can be recommended to use INM practices in sericulture to get a good quality of leaves and better cocoon production.

\section{ACKNOWLEDGEMENT}

The authors are thankful to the Director of Central Tasar Research \& Training Institute for providing lab facilities and the Head of University Department of Botany for his support during the course of investigation. 


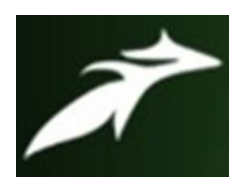

Soma Karmakar et al, International Journal of Advances in Agricultural Science \& Technology, Vol.9 Issue.1, January-2022, pg. 37-47

ISSN: 2348-1358

Impact Factor: 6.846

NAAS Rating: 3.77

\section{REFERENCES}

[1]. Jolly MS, Sonwalker T, Sen SK, Prasad GK.1976.Non-mulberry silks, Sericultural Manual, Food and agriculture Organization of United Nations, Rome.

[2]. Fening KO, Kioko EN, Raina SK, Mueke JM 2008.Monitoring wild silkmoth, Gonometa postica Walker, abundance host plant diversity and distribution in Imba and Mumoni Woodlands in Mwingi, Kenya. International Journal of Biodiversity Science, Ecosystem services and management 4:104-111.DOI:10.3843/Biodiv.4.2:2.

[3]. Bukhari R.,Singh K.P., and Shah R.H.2019.Non-Mulberry sericultures. Journal of Pharmacognosy and Phytochemistry,8(4):311-323.

[4]. Chowdhury P., Setua G.C., Ghosh A., Kar R., Shivnath, Maity S.K. and Bajpai A.K.2009.Organic farming approach for sustainable quality leaf production in mulberry(Morus alba L) var. S-1635 under irrigated condition. Journal of Crop and Weed,5(1):38-43.

[5]. Karlen D.L., Moubach M.J., Doran J.W., Cline R.G., Harris R.F. and Schuman G.E.1997.Soil Sci. Soc. America J., 61,4-10.

[6]. Vishaka GV, Rathore MS, Chandrashekharaiah M, Nadaf HA and Sinha RB 2020.Tasar for Tribes: A way of life. Journal of Entomology and Zoology Stusies.8(1):374-377.

[7]. Srivastava PP, Pandiaraj T , Susmita Das, Sinha SK and Sinha AK 2017. Characteristics of soil Organic carbon, Total Nitrogen and C/N Ratio in Tasar Silkworm growing Regions of Jharkhand and Bihar States. Imperial Journal of Interdisciplinary Research. 3(5):426-429.

[8]. Follet RH, Murphy LS, Donalue RL 1981.Soil-Fertilizer-Plant relationship . Fertilizer Soil Amendment 6(16):478481.

[9]. Edwards CA and Burrows I. 1998. The potential of Earthworm composts as plant growth media.pp.211-220.In: Earthworms in Environmental and waste management, C.A. Edwards and Neuhauser (Eds.)SPB Academic Publ. B.V., The Netherlands.

[10]. Orozo FH, Cegarra J, Trvjillo LM and Roig A 1996.Vermicomposting of Coffee pulp using the earthworm Eisenia foetida: Effects on $\mathrm{C}$ and $\mathrm{N}$ contents and the availability of nutrients.Biol.Fert,Soils.22:162-166.

[11].Hossein Moradi, Mohammad Fahramand, Alireza Sobhkhizi, Mohammad Adibian, Mohsen Noori, Shila Abdollahi and Khashayar Rigi 2014.Effect of vermicompost on plant growth and its relationship with soil properties. Intl J Farm \& Alli. Sci. 3(3):333-338.

[12]. Roe NE ,Stoffella J and Greetz D 1997.Compost from various municipal solid wastes feed stocks affect vegetables crops. II. growth, yield and fruit quality. J. Amer. Soc. Hort.Sci.122:433-437.

[13].Samman, S., Chow, J.W.Y. Foster, M.J. Ahmed, Z.I. Phuyal, J.L. and Petocz, P.2008. Fatty acid composition of edible oils derived from certified organic and conventional agricultural methods. Food Chemistry, 109:670-674.

[14].Wu, S.C., Caob, Z.H., Lib, Z.G., Cheung, K.C. and Wong, M.H.2005,Effects of biofertilizer containing N-fixer, P and $\mathrm{K}$ solubilizers and AM fungi on maize growth: a greenhouse trial.Geoderma.125:155-166.

[15].Sabashini, H.D., Malarvannan, S. and Kumar, P.2007.Effect of biofertilizers on yield of rice cultivars in Pondicherry India. Asian Journal of Agriculture Research,1(3):146-150.

[16]. Kafian Alexandre 1960. Principles for evaluating the nutritional qualities of mulberry leaves, Rev. Ver. Asoie, 12(3):265-278.

[17].Parpiev, B.A.1968. Water metabolism in Silkworms fed with a different mulberry strain changing diet,shelk,39:1517.

[18].Mallapa.,2015. Integrated Nutrient Management in Mulberry (Morus alba L.).M.Sc. thesis. University of Agricultural Sciences. Bangaluru.

[19].Slatyer, R.D.,1955. Studies of the water relations of crop plant grown under natural rainfall in Northern Australia.Aust.J.Agr.Res.6:365-377.

[20].Bower, C.A. and Wilcox, L.V.,1965. Soluble Salts. In: Black, C.A., et al., Methods of Soil Analysis, American Society of Agronomy, Madison,933-940.

[21].Hiscox, J. D. AND Israelstam, G. F., 1979. A method for the estimation of chlorophyll from leaf tissue without maceration. Can. J. Bot., 57: 1332-1334.

[22]. Arnon, O. I., 1949. Copper enzymes in isolated chloroplasts polyphenoxidase; Beta vulgaris. Pl. Physiol., 24: 1-15.

[23].Gomez, K.A. and Gomez, A. A. 1984.Statistical procedures for Agricultural Research. John Willey and Sons. New York, USA.

[24].Das, P.K., Chowdhury, P.C., Ghosh A., Mallikarjuna B., Suryanarayana, N. and Sengupta, K.1990.Effect of green manuring, dry weed and black polythene mulching on soil moisture conservation, growth and yield of mulberry and their economics under rainfed condition. Indian J Seric.,29:263-72.

[25].Setua, G.C., Setua, M., Ghosh, A., Debnath, S., Dutta, A.K., Benerjee, N.D. and Sarkar, A.2007.Effect of integrated nutrient management on sustainable quality leaf production of mulberry (Morus alba) under irrigated alluvial soil conditions.Indian J. Agric.Sci.,77:286-90. 


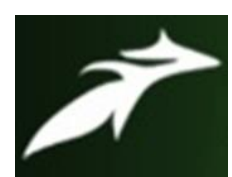

Soma Karmakar et al, International Journal of Advances in Agricultural Science \& Technology, Vol.9 Issue.1, January-2022, pg. 37-47

ISSN: 2348-1358

Impact Factor: 6.846

NAAS Rating: 3.77

[26].Sudhakar, P., Gangawar, S.K., Satpathy, B., Sahu, P. K., Ghosh, J.K. and Saratchandra, B.2000.Evaluation of some nitrogen fixing bacteria for control of foliar disease of Mulberry(Morus alba).Indian J. Seric.,39:9-11.

[27].Khan ,S and Pariari ,A.2012.Effect of N-Fixing biofertilizers on growth,yield and quality of chilli. The Bioscan. 7(3):481-482.

[28].Rashmi, K., Shankar, M.A., Narayanaswamy, T.K., Sreeramula, K.R. and Rajegowda 2006. Effect of application of organic manures and inorganic fertilizers on growth, yield and quality of S36 mulberry. National Conference on New Strategies in Research and Development of Sericulture- India perspective. March 9-10,Banglore University, Banglore(India).pp.36-37.

[29].B. Mallappa, V. Shankaranarayana siddappa and Somanagouda Biradar 2016.Effect of Integrated Nutrient Management on growth and yield of mulberry (Morus alba L.).The Bioscan. 11(2):1303-1305.

[30].P.S. Chaudhuri, T.K. Paul, Animesh Dey, M. Datta, S.K. Dey 2016.Effects of rubber leaf litter vermicompost on earthworm population and yield of pineapple (Ananas comosus) in west Tripura. India Int. J. Recycle Org. Waste Agricult. 5:93-103.

[31].M.K. Singh, S. Roy Chowdhuri, A.H. Naqvi, M.K. Ghosh and B.B. Bindroo 2012.Studies on integrated nutrient management on leaf yield and quality of silk of mulberry (Morus alba $\mathrm{L})$ grown under rainfed situation .Journal of Crop and Weed,8(2):80-82.

[32].Dalal, L.P. and Nandkar, P.B.2006. Effect of Biofertilizers, Macronutroients and Micronutrients on Abelmoschus esculentus(L). The Bioscan. 5(2):267-269.

[33].Rajeswara, Rao, N., Rao, T.V.S.S., Krishna Rao, J.V. and Jayaraj, S 2006.Impact of INM/IPM/IFSM Packages in increasing productivity and sericulture income. Natl. Sem, Soil Health and Water Management for Sustainable Sericulture, $27^{\text {th }}$ and $28^{\text {th }}$ September, Regional Sericultural Research Station(A Unit of CSB).Banglore,India.pp.123-124.

[34].Meenakumari T and Shekhar M 2012. Vermicompost and other fertilizers effect on growth, yield and Nutritional status of Tomato (Lycopersicon esculentum) plant. World Research Journal of Agricultural Biotechnology 1(1):pp-14-16

[35].Pushkarnath 1976. Potato in Sub-tropics. Orient Longman.289p.

[36].Taya JS, YS Mallik, ML Pandita and SC Khurana(1994).Fertilizer management in potato based cropping system1:Growth and Yield of potato. J. Indian Potato Assoc. 21(3-4):184-488.

[37].W. Kerenhap, V. Thiagarajan and V. Kumar 2007. Biochemical and Bioassay studies on the influence of different organic manures on the growth of mulberry Variety $\mathrm{V}_{1}$ and Silkworm Bombyx mori Linn. Caspian J. Env. Sci.,5(1):pp 51-56.

[38].R.L. Ram, S. Chatterjee, C. Maji, P.K. Sharma and Y,V,Singh 2017.Integrated Effect of FYM and potassium Humate on mulberry leaves and Bioassay of Silkworm in Acid soils of Kalimpong Hills. International Journal of Bio-resource and stress management. 8(3):405-412.

[39].Parsons, L.R., and Howe, T.K.1984.Effects of water stress on the water relations of Phaseolus vulgaris and the drought resistant Phaseolus acutifolius. Physiology of plant, 60:197-202.

[40].Montagu, K.D. and K.C. Woo 1999.Recovery of tree photosynthetic capacity from seasonal drought in the wet dry tropics: The role of phyllode and canopy processes in Acacia auriculiformis. Aust. J. Plant Physiol..,26:135-145.

[41].Nilsen, E.T. and D.M. Orcutt 1996.Physiology of plant under stress abiotic factors $2^{\text {nd }}$ edn., John Wiley and Sons. Inc., New York.ISBN:0471170089.pp:689.

[42]. Mirnoff, N.1993. The role of active oxygen in the response of Plants to water deficit and desiccation. New Phytol.,125:27-58

[43].Foyer, C.H., O. Decourvieres and K.J. Kunert 1994.Photo-oxidative stress in Plants. Plant Physiol.,92:696-717.

[44].Lessani, H. and M. Mojtahedi 2002.Introduction to plant Physiology(Translation). $6^{\text {th }}$ edn., Tehran University Press,Iran,ISBN:964-03-3568-1,pp:726.

[45].Nemali K.S., Van lersel MW 2004. Light intensity and fertilizer concentration :I estimating optimal fertilizer concentration from water-use efficiency of Wax begonia .HortScience, 39:1287-1292

[46].Amany S. Al-Erwy, Abdulmoneam Al-Toukhy and Sameera O.Bafeel 2016.Effect of Chemical, organic and biofertilizers on photosynthetic pigments, carbohydrates and minerals of Wheat(Tritium aestivum L.) Irrigated with Sea water. Int. J. Adv. Res. Biol. Sci. 3(2):296-310.

[47].Ray Tucker, M.2004. Primary nutrients and plant growth, In: Essential plant Nutrients, North Carolina Department of Agriculture.

[48].Singhal, B.K., Chakraborti S., Mala, V.R., Sarkar, A. and Datta, R.K.2000. Photosynthesis for crop improvement in mulberry (Morus spp.)-A review. Sericologia,40:27-55.

[49].Rashmi, K., Shankar, M.A., Shashidhar, K.R. and Narayanaswamy, T.K.2009. Growth and foliar constituents of Mulberry (M5) cultivated under organic based nutrient management. Int. J. Indust Entomol. 19(1):165-169. 